TAPPING THE RICHES OF SCIENCE 

Roger L. Geiger and Creso M. Sá

\section{Tapping the Riches of Science}

Universities and the Promise of

Economic Growth 
Copyright @ $\odot 2008$ by the President and Fellows of Harvard College All rights reserved

Printed in the United States of America

Library of Congress Cataloging-in-Publication Data

Geiger, Roger L., 1943-

Tapping the riches of science : universities and the promise of economic growth / Roger L. Geiger, Creso M. Sá.

p. $\mathrm{cm}$.

Includes bibliographical references and index.

ISBN 978-0-674-03128-9

1. Universities and colleges-Economic aspects-United States. 2. Technology transfer-United States. 3. Business and education-United States. 4. Economic development-Effect of education on. I. Sá, Creso M., 1976- II. Title.

LC67.62.G45 2008

$378.1^{\prime} 03-\mathrm{dc} 22$

2008030548 